\title{
Lystarstol 1983-2008 - innlagnir, sjúkdómsmynd og lifun
}

\section{Ágrip}

Tilgangur: Lítið er vitað um nýgengi lystarstols á Íslandi. Markmið rannsóknarinnar var að athuga

Anna

Sigurðardóttir ${ }^{1}$

læknanemi

Sigurður Páll

Pálsson²

geðlæknir

Guollaug

Porsteinsdóttir ${ }^{2}$

geðlæknir

Lykilorð: lystarstol, hliðargeðraskanir, nýgengi, innlagnir, dánartíôni.

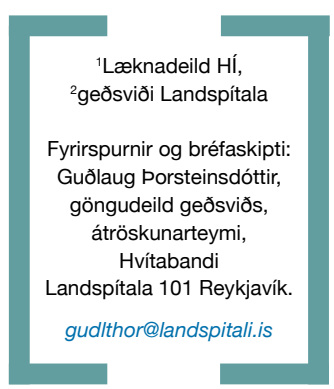
sjúklinga með lystarstol sem lögðust inn á geðdeildir á Íslandi árin 1983-2008.

Efni og aðferðir: Rannsóknin er aftursæ. Skoðaðar voru 140 sjúkraskrár með ICD-9 og ICD-10 greiningarnar lystarstol eða ódæmigerð átröskun. Lokaúrtak var 84 einstaklingar með staðfest lystarstol.

Niðurstöður: Fimm karlar og 79 konur voru lögð inn í fyrsta sinn á geðdeild með lystarstol. Meðalaldur var 18,7 ár. Nýgengi innlagna fyrir bæði kyn á fyrra tímabili (1983-1995) var 1,43 á hverja 100.000 íbúa á ári, 11-46 ára, en á seinna tímabili (1996-2008) 2,91. Aukningin var marktæk ( $R R=2,03$ 95\% CI 1,28-3,22) og má rekja hana til aukins nýgengis innlagna á barna- og unglingageðdeild (BUGL). Dánartíðni lystarstols kvenna var tvær af 79 (2,5\%) og staðlað dánarhlutfall 6,25. Meðallengd fyrstu innlagnar var 97 dagar, 67,3 dagar á fullorðinsgeðdeildum og 129,7 dagar á BUGL $(\mathrm{p}<0,05)$. Á öllu rannsóknartímabilinu lagðist 51 sjúklingur $(60,7 \%)$ inn einu sinni. Einn sjúklingur var nauðungarvistaður í fyrstu innlögn en alls voru tíu (11,9\%) nauðungarvistaðir á öllu tímabilinu. Líkamspyngdarstuðull hækkaði að meðaltali frá innlögn til útskriftar úr 15,3 1́17,5 kg/m². Marktæk fylgni var á milli sjálfsskaða og sjálfsvígstilrauna og nauðungarvistana á geðdeild vegna lystarstols. Ályktanir: Aukning varð á nýgengi innlagna milli tímabila. Hugsanlega endurspeglar pað aukið nýgengi lystarstols í samfélaginu. Dánartíðni var lægri en búist var við.

\section{Inngangur}

Lystarstol (anorexia nervosa) er sú tegund átraskana sem hefur verið talin alvarlegust og erfiðust að meðhöndla. Lystarstol er sjaldgæfur geðsjúkdómur og greinist helst í ungum konum, en fyrir hverjar 12 konur greinist einn karlmaður. ${ }^{1-3}$ Nýgengið er hæst hjá konum á aldrinum 15-19 ára, eða 34,6 á hverjar 100.000 á ári. ${ }^{1,2}$

Íslenska pýðingin á anorexia nervosa, lystarstol, nýgengi innlagna, sjúkdómsmynd og dánartíðni gefur ekki rétta mynd af sjúkdómseinkennum pví ekki er um að ræða eiginlegt lystarleysi heldur neita sjúklingar sér um mat af ótta við að pyngjast og verða pví óeðlilega magrir. Lystarstoli var fyrst lýst árið 1870 og var lýsingin mjög svipuð peim greiningarviðmiðum sem notuð eru í dag. Lystarstoli er par lýst sem röskun sem einkennist af pví að sjúklingur léttir sig meðvitað vegna pess að honum finnst hann vera of pungur prátt fyrir að vera í undirpyngd. Sjúklingur ofmetur pyngd sína og verður upptekinn af pví að reyna að megra sig með mjög pröngum kosti, óhóflegum líkamsæfingum og jafnvel losunarhegðun, pað er að kasta upp mat eða misnota hægða- eða pvagræsilyf. Pyngdartapið veldur að lokum vannæringu með röskun á hormónastarfsemi, sem sést best á röskun á undirstúku-kynkirtlaöxli, en hún veldur tíðastoppi hjá konum og kyndeyfð hjá körlum., ${ }^{4,5}$

Sjúklingur fær greininguna ódæmigert lystarstol pegar ekki öll greiningarviðmið lystarstols eru uppfyllt, til dæmis ef líkamspyngdarstuðull er ekki kominn undir 17,5 en til staðar er marktækt pyngdartap og hegðun sem miðar að pví að léttast frekar. $^{5}$

Lystarstol getur próast í alvarlegan sjúkdóm og leitt til langvarandi færniskerðingar og veikinda, jafnvel dauða. Í yfirlitsgrein Steinhausen ${ }^{6}$ par sem skoðaðar eru 119 rannsóknir á lystarstolssjúklingum kemur fram að dánartíðni er að meðaltali 5,0\% og staðlað dánarhlutfall frá 1,36-17,8. ${ }^{6}$ Í danskri rannsókn á lystarstolssjúklingum sem lagðir voru inn á geð- og lyflækningadeildir 1970-1993 var dánartíðnin 8,4\% og staðlað dánarhlutfall 6,69. ${ }^{7}$ Lystarstol er með hæstu dánartíðni meðal geðsjúkdóma og er dánarhlutfall 9,6 fyrir öll dauðsföll. Sjálfsvíg er langalgengasta dánarorsökin. ${ }^{7}$

Við ítarlega heimildaleit í gagnagrunnum fannst aðeins ein rannsókn sem skoðar nýgengi innlagna lystarstolssjúklinga á geðdeildir. Sú rannsókn var gerð í Danmörku og var byggð á geðsjúkdómaskrá árin 1973-1987. Par kom fram að meðalnýgengi var 1,9/100.000 á ári fyrir konur en 0,17/100.000 á ári fyrir karla. ${ }^{8}$

Lítið er vitað um faraldsfræði lystarstols á Íslandi og engar upplýsingar eru til um nýgengi pess. Ein rannsókn sem var birt fjallaði um al- 


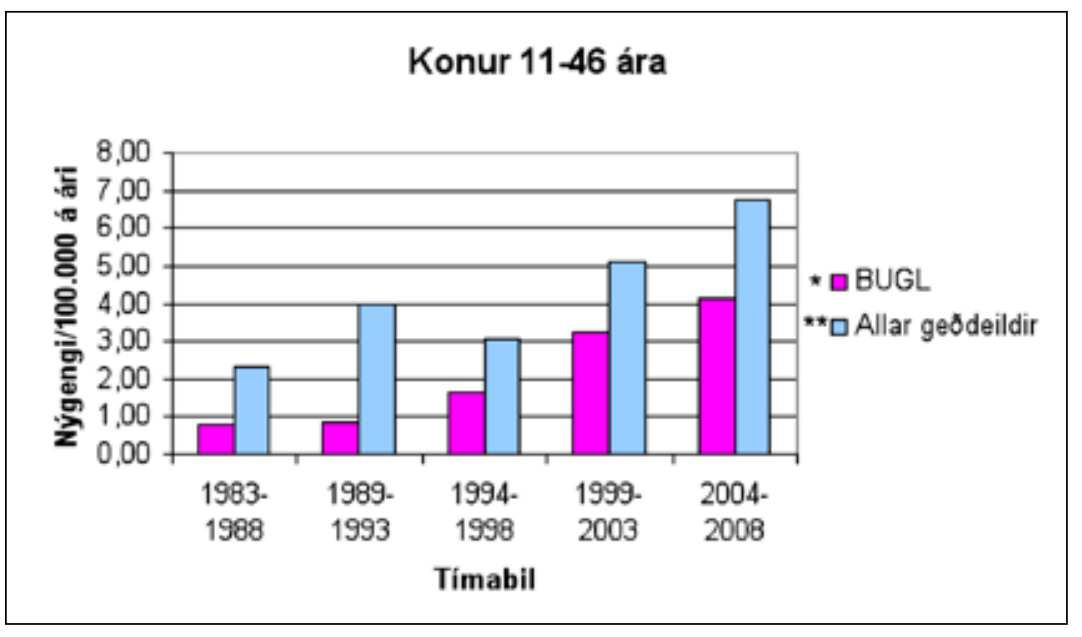

Mynd 1. Nýgengi 11-46 ára kvenna med lystarstol á geðdeildum á Íslandi 1983-

2008.

*BUGL: Barna- og unglingageðdeild. **Allar geđdeildir: allar geđdeildir a Íslandi, par með talið BUGL.

gengi átraskana hjá framhaldsskólanemum (1620 ára, N=3052 ) á Íslandi á árunum 2004-2005, en pá greindust $1,1 \%$ stúlkna með lystarstol samkvæmt átröskunarspurningalista, en enginn piltur. ${ }^{9}$ Önnur nýleg íslensk grein fann engin tilfelli (algengi) lystarstols í pýði 405 einstaklinga á aldrinum 34-76 ára. ${ }^{10}$

Tilgangur pessarar rannsóknar er að lýsa nýgengi lystarstols á geðdeildum á Íslandi á tímabilinu 1983-2008 og lifun einstaklinganna. Rannsökuð eru tengsl lystarstols við aðrar geðraskanir, sjálfsskaðandi hegðun og sjálfsvígstilraunir. Pá eru tíðni endurinnlagna vegna lystarstols, breytingar á líkamspyngdarstuðli í innlögn, geðlyfjanotkun og fjöldi nauðungarvistana einnig skoðuð á tímabilinu.

\section{Efni og aðferöir}

Rannsóknin er aftursæ og byggir á sjúkraskrám allra sem voru lagðir inn á geðdeildir á Íslandi á tímabilinu 1. janúar 1983 til 31. desember 2008 og fengu greininguna lystarstol eða ódæmigert lystarstol í læknabréfi. Petta eru barna- og unglingageðdeild Landspítala (BUGL), geðdeild Fjórðungssjúkrahúss Akureyrar (FSA), deild A2 á

Tafla I. Próun innlagna nýrra tilfella af lystarstoli á geðdeildum á Íslandi miðað við pjóðarpýði 11-46 ára. Hlutfallsleg áhætta á 5 ára tímabilum.

\begin{tabular}{lccccc}
\hline Tímabil & Ný tilfelli & Í áhættu á tímabili & RR & Vikmörk 95\% & p-gildi \\
\hline $1983-1988^{*}$ & 9 & 800766 & 1,00 & $0,40-2,52$ & - \\
\hline $1989-1993$ & 14 & 716964 & 1,74 & $0,75-4,01$ & 0,214 \\
\hline $1994-1998$ & 11 & 735440 & 1,33 & $0,55-3,21$ & 0,655 \\
\hline $1999-2003$ & 22 & 757396 & 2,58 & $1,19-5,61$ & 0,018 \\
\hline $2004-2008$ & 28 & 792637 & 3,14 & $1,48-6,66$ & 0,001 \\
\hline
\end{tabular}

‡Kví próf M-H fyrir „linear trend“ $=11,7 ; p=0,001$ yfir allt tímabil.

${ }^{*}$ Fyrsta tímabil er sex ár og er viðmiðunartímabil, hin tímabilin eru fimm ár.
Borgarspítala (páverandi geðdeild) og geðdeildir Landspítala/Kleppsspítala. Til að finna úrtakið voru skoðaðar sjúkraskrár peirra sem höfðu fengið eftirtaldar greiningar á læknabréfi: F50.0 og F50.1 úr ICD-10 sjúkdómaflokkunarkerfinu og 307.1 og 307.5 úr ICD-9 kerfinu. Allar sjúkraskrár einstaklinga sem höfðu lystarstol annaðhvort sem megingreiningu eða aukagreiningu voru skoðaðar.

Sjúkraskrár fundust á skjalasafni Landspítala og FSA fyrir alla sjúklingana ( $\mathrm{N}=140)$ og var farið ítarlega í gegnum pær til að meta áreiðanleika greininga og safna upplýsingum. Læknanemi (AS) fór yfir sjúkraskrár og sannreyndi að upplýsingar uppfylltu greiningarskilmerki ICD. Ef einhver vafi lék á réttmæti greininga var pað borið undir sérfræðinga í geðlækningum (GP og SPP).

Alls voru 140 sjúkraskrár skoðaðar en 56 einstaklingar voru útilokaðir og rannsóknarhópurinn pví 84 manns. Ástæður pess að sjúklingar voru útilokaðir voru eftirfarandi: greiningin 307.5 (aðrar og ósértækar átraskanir) par sem sjúklingar reyndust ekki vera með lystarstol (24); lystarstolsgreining sem ekki var hægt að sannreyna út frá sjúkraskrá par sem upplýsingar skorti (24); prír sjúklingar sem komu á bráðamóttöku og lágu skemur en einn sólarhring inni; fimm einstaklingar sem fengu meðferð á dagdeild átraskana, sem stofnuð var 1. febrúar 2006 en slíkt úrræði hafði ekki áður verið til á Íslandi, en lögðust ekki inn í sólarhringsinnlögn.

Sjúkraskrár peirra sem lögðust inn á lyflækninga- og barnadeildir vegna lystarstols á rannsóknartímabilinu voru skoðaðar. Petta var gert til að skoða hversu mörgum einstaklingum rannsóknin missti af og gætu breytt nýgengi innlagna á geðdeildum eftir tímabilum. Prjár konur fundust á fyrra tímabili (1983-1995) en fimm á seinna (19962008).

Lifun sjúklinga var athuguð hjá pjóðskrá og miðað var við 1. mars 2009.

Unnið var úr niðurstöðum í tölfræðiforritunum SPSS 17.0 og Microsoft Excel. Við tölfræðilega úrvinnslu voru notuð kí-kvaðrat próf ef breytan var raðbreyta, en ef breytan var samfelld var notað t-próf. Gerð voru stikalaus próf (e. non-parametric) ef hópar voru smáir. Pau voru Fisher Exact, Mann-Whitney test og Spearman's rank correlation coefficient. Marktektarmörk voru $\mathrm{p}<0,05$.

Nýgengi var reiknað sem fjöldi nýrra innlagna á geðdeildir á tímabilinu. Nýgengi (I) er skilgreint sem ný tilfelli á áhættutíma, I = A (ný sjúkdómstilfelli í hópi)/ $\mathrm{R}$ (peim fjölda einstaklinga sem er í áhættu á að fá sjúkdóminn á tímabilinu)., 11,12 Við útreikninga á hlutfallslegri áhættu tímabila var forritið Win Episcope 2.0 notað. 
Samræmt dánarhlutfall var reiknað sem hlutfall látinna sjúklinga á rannsóknartímabili deilt með hlutfalli áætlaðra dauðsfalla sambærilegs pjóðarpýðis á tímabilinu.

Upplýsingar um sjálfsvígstilraunir og sjálfsskaðandi hegðun fengust úr skrifuðum nótum 1 sjúkraskrám og stöðluðum spurningalistum sem hluti sjúklinga hafði fyllt út í legu sinni á geðdeild.

Hliðargeðraskanir voru aðrar ICD geðraskanir sem einstaklingar fengu á öllu rannsóknartímabilinu samkvæmt sjúkraskrá. Petta var óháð fyrstu innlögn.

Tilskilin leyfi fyrir rannsókninni fengust hjá Vísindasiðanefnd, Persónuvernd og lækningaforstjórum Landspítala og Fjórðungssjúkrahúss Akureyrar.

\section{Niðurstöður}

Rannsóknartímabilið var 26 ár og var pví skipt upp í tvö jafnlöng tímabil við tölfræðigreiningu. Fyrra tímabilið var frá 1983-1995 og hið síðara frá 19962008. Niðurstöður voru pær að 84 einstaklingar af $140(60 \%)$ reyndust með öruggri vissu vera með lystarstol, par af prír með ódæmigert lystarstol.

Konur voru 79 talsins (94\%) og voru á aldrinum 11-46 ára. Karlar voru fimm (6\%) og á aldrinum 12-22 ára. Meðalaldur við fyrstu innlögn var 18,7 ár $( \pm 5,8)$ og varð ekki marktæk breyting milli tímabila.

Á fyrra tímabili voru 26 sjúklingar lagðir inn en 58 á seinna tímabili. Nýgengi kvenna jókst marktækt, úr 2,93/100.000 á ári í 5,42 ( $R R=1,85$; 95\% CI 1,16-2,95). Nýgengi kvenna yfir allt tímabilið var 4,24/100.000 á ári. Nýgengi karla var 0,80/100.000 á ári fyrir allt tímabilið. Nýgengi fyrir bæði kyn var 1,43/100.000 á ári á fyrra tímabili og 2,91 á pví seinna. Fjölgun innlagna var mest á BUGL, eins og sjá má á mynd 1. Nýjum innlögnum lystarstolssjúklinga á BUGL fjölgaði úr sex sjúklingum á fyrra tímabili (23,1\% af heildarfjölda) í 34 (58,6\% af heildarfjölda) á seinna tímabili. Á fullorðinsgeðdeildir lögðust 20 sjúklingar inn á fyrra tímabili, en 24 á pví seinna.

Eins og sést á mynd 1 virðist nýgengið lækka á miðju rannsóknartímabilinu. Tafla I sýnir nákvæma próun nýgengis á fimm tímabilum. Niðurstöður sýna að marktæk aukning nýgengis innlagna var á síðustu tveimur fimm ára tímabilunum. Marktæk línuleg aukning nýgengis innlagna reiknast yfir allt tímabilið $(\mathrm{p}=0,001)$.

Tveir sjúklingar úr pýðinu voru látnir pann 1.3.2009. Báđir voru konur og er pví dánartíðni kvenna 2,5\%. Meðaleftirfylgdartími var 10 ár (spönn 4 mánuðir til 25,5 ár). Dánartíðni pjóðarpýðis af sama kyni, aldri og tímabili ${ }^{13}$ eftir
Tafla II. Hlutfall lystarstolssjúklinga sem hlutu hliðargeðraskanir við fyrstu innlögn á geðdeild, borið saman milli tímabila.

\begin{tabular}{lccc}
\hline Geðraskanir & $\begin{array}{c}\text { Fyrra tímabil } \\
(1983-1995) \mathrm{N}(\%)\end{array}$ & $\begin{array}{c}\text { Seinna tímabil } \\
(1996-2008) \mathrm{N}(\%)\end{array}$ & p-gildi \\
\hline Fíkniraskanir & $0(0)$ & $6(10,3)$ & 0,170 \\
\hline Geðrof & $0(0)$ & $0(0)$ & - \\
\hline Lyndisraskanir & $4(15,4)$ & $15(25,9)$ & 0,401 \\
\hline Kvíðaraskanir & $1(3,8)$ & $8(13,8)$ & 0,263 \\
\hline Persónuleikaraskanir & $1(3,8)$ & $4(6,9)$ & 1,000 \\
\hline Aðrar átraskanir & $2(7,7)$ & $2(3,4)$ & 0,584 \\
\hline ADHD (ofvirkni og athyglisbrestur) & $0(0)$ & $5(8,6)$ & 0,318 \\
\hline
\end{tabular}

að leiðrétt hafði verið fyrir eftirfylgdartíma var 0,4

$\%$. Petta er marktækt hækkuð dánartíðni $(p<0,01)$ og samræmt dánarhlutfall er 6,25. Konurnar létust ekki af völdum vannæringar.

Greiningar annarra geðsjúkdóma í hópnum í fyrstu innlögn jukust ekki marktækt milli tímabilanna tveggja (tafla II). Á fyrra tímabili hlutu sjö sjúklingar (30,8\%) hliðargeðgreiningu en 24 sjúklingar $(39,7 \%)$ á seinna tímabilinu. Munurinn á pessu var ekki marktækur.

\section{Legutími}

Legutími fyrstu innlagnar á geðdeild var frá tveimur dögum upp í tæpt eitt og hálft ár (526 dagar), en meðallegutíminn var um 97 dagar yfir allt tímabilið. Meðallegutíminn jókst úr 86 dögum í 102 daga frá fyrra til seinna tímabils, en náđi ekki marktækni. Hins vegar var marktækur munur $(\mathrm{p}=0,007)$ á legutíma á fullorðinsgeðdeildum annars vegar $(67,3$ dagur, $\pm 8,8)$ og BUGL hins vegar (129,7 dagar, $\pm 20,5)$. Legutími á BUGL jókst úr 71,2 degi á fyrra tímabili í 142,0 daga á seinna tímabili. Á fullorðinsgeðdeildum fækkaði legudögum marktækt úr 90,0 á fyrra tímabili í 48,3 á seinna $(\mathrm{p}=0,024)$.

Yfir allt tímabilið lagðist 51 (60,7\%) sjúklingur inn einu sinni, $22(26,2 \%)$ sjúklingar tvisvar til fjórum sinnum og 11 (13,1\%) sjúklingar fimm sinnum eða oftar. Fjöldi innlagna á hvern lystarstolssjúkling var frá einni upp í 28. Munur á meðalfjölda endurinnlagna á fyrra og seinna tímabili var ekki marktækur, en meðalfjöldi innlagna var 2,8 á fyrra tímabili og 2,3 á seinna. Á fyrra tímabili voru 7,7\% sjúklinganna lagðir inn fimm sinnum eða oftar og 15,5\% á seinna tímabili.

\section{Nauð̌ungarvistanir}

Einn sjúklingur var nauðungarvistaður í fyrstu innlögn en alls voru tíu sjúklingar (11,9\%) nauðungarvistaðir á einhverjum tímapunkti á öllu rannsóknartímabilinu. Jákvæð fylgni var milli pess hvort sjúklingur hafði reynt sjálfsvíg og hvort 
Tafla III. Geðlyfjameðferð i fyrstu legu lystarstolssjúklinga á geðdeild, borin saman milli tímabila.

\begin{tabular}{lccc}
\hline Lyf & $\begin{array}{c}\text { Fyrra tímabil } \\
(1983-1995) \mathrm{N}(\%)\end{array}$ & $\begin{array}{c}\text { Seinna tímabil* } \\
(1996-2008) \mathrm{N}(\%)\end{array}$ & p-gildi \\
\hline Punglyndislyf & $6(23,1)$ & $37(64,9)$ & 0,001 \\
\hline Sefandi lyf & $2(7,7)$ & $20(35,1)$ & 0,008 \\
\hline Róandi lyf & $5(19,2)$ & $7(12,3)$ & 0,503 \\
\hline Andhistamín & $3(11,5)$ & $4(7,0)$ & 0,672 \\
\hline *Upplýsingar vantaði um einn einstakling. & & \\
\hline
\end{tabular}

hann hafi verið nauðungarvistaður $\left(r_{s}=0,324\right.$, $\mathrm{p}=0,003)$. Að sama skapi var fylgni milli annarrar sjálfsskaðandi hegðunar og nauðungarvistunar $\left(r_{s}=0,226, p=0,045\right)$. Meðalfjöldi innlagna á hvern sjúkling sem var nauðungarvistaður var 7,9 en 1,7 fyrir pá sem aldrei voru nauðungarvistaðir $(\mathrm{p}=0,032)$.

\section{Pyngdaraukning í innlögn}

Meðallíkamspyngd í fyrstu innlögn jókst marktækt $(p<0,01)$ frá innlögn til útskriftar, en sjúklingar pyngdust að meðaltali um $5,9 \mathrm{~kg} 1$ innlögninni. Meðal líkamspyngdarstuðull við fyrstu innlögn var svipaður milli tímabila, 15,9 á fyrra og 15,5 á seinna. Líkamspyngdarstuðull við útskrift var að meðaltali aðeins hærri á seinna $(17,8)$ en á fyrra tímabili $(16,8)$, en náði ekki marktækni. Dreifing líkamspyngdarstuðuls við fyrstu innlögn yfir allt tímabilið var 11,9-22,2 kg/ $\mathrm{m}^{2}$, en jókst að meðaltali frá innlögn til útskriftar úr 15,3 í17,5 kg/m² (p<0,01). Enginn tölfræðilegur munur var á pyngdaraukningu sjúklinga á BUGL milli fyrra og síðara tímabils. Sama átti við um sjúklinga á fullorðinsgeðdeildum.

Neikvæð fylgni var milli líkamspyngdarstuðuls við fyrstu innlögn og tímalengdar innlagnarinnar ( $\mathrm{r}=-0,219, \mathrm{p}=0,048)$, pað er pví lægri sem pyngdarstuðull var við innlögn, pví lengri var lega sjúklinganna á geðdeild.

Marktæk aukning varð á meðferð með punglyndislyfjum $(p<0,01)$ og geðrofslyfjum $(p<0,01)$ frá fyrra tímabili til seinna, en meðferð með andhistamínum og róandi lyfjum minnkaði lítillega (tafla III).

\section{Sjálfsskaðandi hegðun og sjálfsvígstilraunir}

Tuttugu og fimm sjúklingar (29,8\%) gerðu eina eða fleiri sjálfsvígstilraunir á öllu tímabilinu. Prjátíu og prír sjúklingar (39,3\%) sýndu einu sinni eða oftar sjálfsskaðandi hegðun sem taldist ekki til sjálfsvígstilraunar.

Sjálfsvígstilraun var skilgreind sem verknaður af ásettu ráði sem leitt hefði getað til dauða ef inngrip hefði ekki komið til (til dæmis lyfjainntaka, djúpur blæðandi skurður eða skurður á hættulegu svæði eins og hálsi).

Sjálfsskaðandi hegðun var skilgreind sem minni háttar sjálfsáverkar par sem nánast var útilokað að viðkomandi hefði látist (til dæmis yfirborðslegar rispur, að lemja höfðinu í vegg eða klípa sig og klóra).

Sextán peirra 25 sem reyndu sjálfsvíg höfðu einnig sögu um sjálfsskaðandi hegðun á rannsóknartímabilinu. Átján peirra 33 sem stunduðu sjálfsskaðandi hegðun höfðu einnig sögu um sjálfsvígstilraun. Hlutfallslega fleiri sýndu sjálfsskaðandi hegðun á seinna tímabilinu, en pað náði ekki marktækni.

Flestir sem leituðu á slysa- og bráđamóttöku vegna sjálfsvígstilraunar höfðu tekið inn ofskammt lyfja (n=16). Fimm sjúklingar leituðu til slysa- og bráðamóttöku vegna skurða í sjálfsvígstilgangi.

\section{Umræða}

Rannsóknin sýnir að nýgengi innlagna vegna lystarstols á geðdeildum á Íslandi hækkaði marktækt milli tímabilanna 1983-1995 og 19962008. Línulegur stígandi greindist á nýgengi innlagna yfir allt tímabilið. Hjá konum varð tæplega tvöföldun á nýgengi. Aukninguna má rekja til fleiri innlagna á BUGL, en nýgengið hélst svipað á fullorðinsgeðdeildum.

Dánartíðni var hærri hjá konum með lystarstol en í stöðluðu pjóðarpýði fyrir aldur, kyn og eftirfylgdartíma. Hins vegar var dánartíðnin lág, 2,5\% (samræmt dánarhlutfall 6,25), miðað við langan eftirfylgdartíma par sem aðrar erlendar rannsóknir hafa sýnt dánartíðni á bilinu 5-9\%.6,7 Ástæða lægri dánartíðni hér á landi gæti verið gott aðgengi að íslensku heilbrigðiskerfi og góð pjónusta. Félagslegur stuðningur og náin tengsl innan fjölskyldna gætu einnig verið verndandi pættir. Konurnar sem létust í pessari rannsókn létust ekki af völdum vannæringar og höfðu ýmsa af peim áhættupáttum sem vitað er að valda verri horfum lystarstolssjúklinga (tafla IV).

Eina hliðstæða rannsóknin ${ }^{8}$ sem fannst var gerð í Danmörku á árunum 1973-1987 par sem aukningu á nýgengi innlagna var einnig lýst. Nýgengi yfir allt tímabilið var pað sama í dönsku rannsókninni og í pessari rannsókn. Nýgengi karla á öllu tímabilinu í íslensku rannsókninni var undir 1,0/100.000 á ári, í samræmi við pað sem hefur áður verið birt. ${ }^{3,8}$ Danska rannsóknin er byggð á miðlægum gagnagrunni, án pess að farið sé yfir sjúkraskrár til að sannreyna réttmæti 
greininga og rannsóknartímabilið var annað. Petta gerir samanburðinn á rannsóknunum erfiðan.

Pó að hugsanlega geti verið um að ræða raunverulega aukningu á lystarstoli í almennu pýði á Íslandi, er erfitt að álykta um pað út frá pessari rannsókn. Innlagnir á geðdeildir vegna alvarlegs lystarstols endurspegla aðeins lítinn hluta lystarstolssjúklinga, pví aðeins veikustu sjúklingarnir leggjast inn. Erlendis virðist nýgengi lystarstolssjúklinga í almennu pýði ekki hafa aukist á undanförnum árum ${ }^{1,8,14}$ en rannsóknir vantar á Íslandi. Innlagnarpröskuldurinn hefur hins vegar ekki lækkað ef miðað er við líkamspyngdarstuðul við innlögn, pannig að pað skýrir ekki aukninguna. Hugsanlega gæti hafa orðið breyting á pjónustu dag- og göngudeilda BUGL á tímabilinu og pað leitt til fleiri innlagna, en engar öruggar upplýsingar lágu fyrir um pjónustu eða verklag heilsugæslu og skóla á pessu tímabili. Dagdeild átraskana var stofnuð árið 2006 á fullorðinsgeðdeild og á árunum 2006-2008 fengu fimm nýgreindir sjúklingar með lystarstol meðferð á henni, en mögulegt er að peir hefðu ella lagst inn á sólarhringsgeðdeild og nýgengi innlagna pví orðið enn hærra á seinna tímabilinu.

Legur sjúklinga á geðdeildum eru oft langar og erfiðar og pví brýnt að vel takist til. Рað er áhyggjuefni hversu há tíðni endurinnlagna (40\%) er á öllu tímabilinu og á seinna tímabilinu (19962008) eykst fjöldi peirra sem leggjast inn fimm sinnum eða oftar. Petta endurspeglar veikasta hluta sjúklingahópsins og skort á viðeigandi meðferðarúrræðum eftir útskrift af geðdeild. Aldursdreifing og meðalaldur við fyrstu innlögn í sjúklingahópnum virðist vera svipuð og erlendis ${ }^{3}$ en par hefur meðalaldur við fyrstu innlögn haldist óbreyttur síðustu 40 árin. ${ }^{14}$

Geðlæknar tilgreindu oftar hliðargeðraskanir á seinna tímabilinu. Fáir sjúklingar fengu kvíðaraskanagreiningu og pó að algengi kvíðaraskana hafi hækkað upp í 13,8\% á seinna tímabili var pað umtalsvert lægra en búist hafði verið við, par sem lífsalgengi erlendis hefur verið lýst allt að $80 \% .^{15}$ Einnig er athyglisvert hve fáir fengu fíkniraskanagreiningu á tímabilinu. Ný bandarísk/evrópsk rannsókn sýnir að um 20\% sjúklinga með lystarstol próa með sér áfengisfíkn á lífsleiðinni og tæplega 26\% lyfjafíkn. ${ }^{16}$ Eru peir í sérstakri áhættu sem stunda átköst/losunarhegðun samhliða svelti.

Meðallegutími jókst úr 86 dögum í 102 frá fyrra til seinna tímabils, en munurinn náði ekki marktækni. Meðallegutími styttist marktækt á fullorðinsgeðdeildum á seinna tímabilinu en par varð mikil fækkun legurýma á milli tímabila. Virðist sem prýst hafi verið á hraðari
Tafla IV. Pættir sem hafa áhrif á horfur lystarstolssjúklinga. ${ }^{6,23}$

\begin{tabular}{ll}
\hline Verri horfur & Betri horfur \\
\hline Hærri aldur við greiningu & Lægri aldur við greiningu \\
\hline Mikið pyngdartap & Lítið pyngdartap \\
\hline Langvinnt lystarstol & Sjúkdómseinkenni vara stutt \\
\hline Losunarhegðun, til dæmis uppköst & Lystarstol, aðhaldsgerð (e. restrictive AN) \\
\hline Áráttu- og práhyggjueinkenni & Lítilengin áráttu- og práhyggjueinkenni \\
\hline Röskuð tengsl innan fjölskyldu & Gott samband við foreldra/maka \\
\hline Félagsleg vandamál & Góð efnahags- og félagsstaða \\
\hline Persónuleikaraskanir & Sefasýkis persónuleikapættir (e. hysteric) \\
\hline Fíkniraskanir (mest áfengissýki) & Fyrri innlögn vegna geðslagsraskana \\
\hline
\end{tabular}

pyngdaraukningu í innlögnum á seinna tímabili til að stytta legutíma og pað síðan leitt til aukins fjölda endurinnlagna. Legutími á BUGL lengdist og er pað vandtúlkað vegna smæðar úrtaks. Meðallegutíminn virðist svipaður og lýst hefur verið í Bandaríkjunum. ${ }^{17}$ Í nýlegri franskri rannsókn var meðallegutími vegna lystarstols 135 dagar hjá sjúklingum á aldrinum 12-22 ára. ${ }^{18}$

Meiri geðlyfjanotkun á seinna tímabili skýrist að mestu leyti af aukinni notkun nýrra geðrofslyfja sem auka matarlyst og slá á kvíða og depurð. Eru pað aðallega olanzapín, quetiapín og risperídón sem hafa verið notuð. Notkun peirra við lystarstoli hefur byggst meira á tilraunagrunni en að rannsóknir hafi raunverulega getað staðfest verkun peirra. Pessi lyf hafa reynst öruggari og auðveldari í notkun en eldri geðrofslyf og hefur pað hugsanlega ýtt undir aukna notkun á peim. Ástæða er til að vera gagnrýnin á notkun pessara lyfja og velja vel pá sjúklinga sem gætu haft gagn af peim. Svipaða aukningu á notkun geðlyfja má sjá erlendis, pó góðar rannsóknir vanti enn. ${ }^{19}$

Markmið rannsóknarinnar var ekki að meta árangur meðferðar en pó var skoðuð ein mælistika sem var pyngdaraukning í innlögn. Sjúklingar pyngdust að meðaltali um 5,9kg, sem er góður árangur. Samt sem áður útskrifast sjúklingar að meðaltali undir kjörpyngd (líkamspyngdarstuðull $<17,5)$ og hefur pví pyngdarmarkmiðum í mörgum tilvikum ekki verið náð, en pað gæti aukið líkur á endurinnlögn.

Ólíkt erlendum rannsóknum ${ }^{20}$ var ekki fylgni milli pess hvort sjúklingur var nauðungarvistaður og pess hvort hann fékk hliðargeðraskanir á tímabilinu. Niðurstöður okkar sýndu pó tilhneigingu í pá áttina $\left(\mathrm{r}_{\mathrm{s}}=0,205, \mathrm{p}=0,061\right)$. Einungis einn sjúklingur af 44 sem lögðust inn á fullorðinsgeðdeildir var nauðungarvistaður í fyrstu innlögn og verður pað að teljast lágt, pó erfitt sé að finna samanburðartölur. Hins vegar voru níu sjúklingar til viðbótar nauðungarvistaðir í endurinnlögnum og voru pví 
11,9\% nauðungarvistaðir á einhverjum tímapunkti í veikindunum. Nauðungarvistun er ávallt umdeild aðgerð og ætti einungis að beita henni ef sjúklingi er lífshætta búin vegna vannæringar eða sjálfsvígshættu. Hvort pvingunum er beitt of mikið eða of lítið miðað við önnur lönd, er erfitt að segja par sem löggjöfin er ekki sú sama, en tíðni nauðungarvistana vegna lystarstols hefur verið lýst frá 4-30\% á Vesturlöndum. ${ }^{21}$ Peir sem hafa verið nauðungarvistaðir eru líklegri en aðrir til að hafa áður verið lagðir inn vegna lystarstols, sýnt sjálfsskaðandi hegðun og/eða gert sjálfsvígstilraun. Niðurstöður okkar sýna hækkandi tíðni sjálfsskaðandi hegðunar milli tímabila en tíðni sjálfsvígstilrauna var há og hélst óbreytt. Pessar niðurstöður eru í samræmi við erlendar rannsóknir sem sýnt hafa tíðnina 13$68 \% .^{22}$

Styrkur pessarar rannsóknar er áreiðanleiki sjúkdómsgreininga í sjúklingahópnum. Sá mikli fjöldi sem útilokaður var úr upphaflega pýðinu sýnir hversu óáreiðanlegar rannsóknir geta verið ef pær byggja eingöngu á tölum frá miðlægum gagnagrunnum. Vegna smæðar Íslands var hægt að gera rannsókn sem náði yfir allar geðdeildir landsins og fáum við pví yfirsýn yfir heila pjóð. Eðli málsins samkvæmt er pví erfitt að finna samanburðarrannsókn í öðrum löndum. Langur eftirfylgdartími, að meðaltali tæp tíu ár, (bil fjórir mánuðir til 25,5 ár) er einnig styrkur og flestar breytur sem leitað var að höfðu verið skráðar í sjúkraskrá.

Veikleiki rannsóknarinnar er helst hversu rannsóknarhópurinn er lítill $(\mathrm{N}=84)$ en pað er bein afleiðing smæðar pjóðarinnar. Hins vegar voru niðurstöður okkar sambærilegar við hliðstæða rannsókn frá Danmörku. ${ }^{8}$ Pó að lifun sjúklinga sé betri samkvæmt pessari rannsókn en erlendis, ${ }^{6,7}$ segir pað ekki til um hver raunverulegur bati peirra var á tímabilinu. Ekki var hægt að skoða hvort ákveðin fæðingartímabil hefðu áhrif á nýgengið. Mögulegt er að rannsóknin hafi misst af sjúklingum með lystarstol sem lagst hafa inn vegna annarra alvarlegra geðraskana, eins og alvarlegs punglyndis, geðrofssjúkdóma eða alvarlegs fíknisjúkdóms. Hafa pá lystarstolseinkenni fallið î skuggann og ekki verið greind.

\section{Lokaord}

Ljóst er að fáir sjúklingar leggjast inn á geðdeildir á Íslandi vegna lystarstols, en innlagnir eru langar og endurinnlagnir algengar. Sjúklingar hafa flókna og margbreytilega sjúkdómsmynd par sem sjálfsvígstilraunir og sjálfsskaði eru algeng. Áherslur í framtíðinni hljóta að vera að bæta pjónustu við sjúklinga og fjölskyldur peirra. Mikilvægt er að próa fjölbreyttari eftirmeðferðarúrræði með mismunandi parfir sjúklinga í huga. Hugmynd að eftirfylgdarrannsókn væri að fá sjúklingana í klínískt viðtal, meta hversu margir hafa náð fullum bata og hvernig peir upplifðu innlögn á geðdeildum.

Frekari faraldsfræðirannsóknir um sjúklinga með lystarstol vantar hér á landi, sem og að skoða hvort lystarstol sé að aukast í almennu pýði.

Pakkir fá læknaritarar geðdeildar Landspítala og barna- og unglingageðdeildar.

\section{Heimildir}

1. Currin L, Schmidt U, Treasure J, Jick H. Time trends in eating disorder incidence. Br J Psychiatry 2005; 186:132-5.

2. Hoek HW. Incidence, prevalence and mortality of anorexia nervosa and other eating disorders. Curr Opin Psychiatry 2006; 19: 389-94.

3. Hoek HW, van Hoeken D. Review of the prevalence and incidence of eating disorders. Int J Eat Disord 2003; 34: 38396.

4. Klein DA, Walsh BT. Eating disorders: clinical features and pathophysiology. Physiol Behav 2004; 81: 359-74.

5. The ICD-10 Classification of Mental and Behavioral Disorders: Diagnostic Criteria for Research. World Health Organisation, Geneva 1993.

6. Steinhausen HC. The outcome of anorexia nervosa in the 20th century. Am J Psychiatry 2002; 15: 1284-93.

7. Emborg C. Mortality and causes of death in eating disorders in Denmark 1970-1993: a case register study. Int J Eat Disord 1999; 25: 243-51.

8. Nielsen S. The Epidemiology of Anorexia-Nervosa in Denmark from 1973 to 1987 - a Nationwide Register Study of Psychiatric Admission. Acta Psychiatr Scand 1990; 81: 507-14.

9. Thorsteinsdottir G, Ulfarsdottir L. Eating disorders in college students in Iceland. Eur J Psychiatr 2008; 22: 107-15

10. Stefánsson JG, Líndal E. Algengi geðraskana á StórReykjavíkursvæðinu. Læknablaðið 2009; 95: 559-64.

11. Ahlbom A. Biostatistik för epidemiologer. Appendix med övningsopgifter och lösningar av Lars Alfredsson. Studentlitteratur, Lund 1990.

12. Ahlbom A, Norell S. Grunderna i Epidemiologi. Studentlitteratur, Lund 1987.

13. Hagstofa Íslands. Mannfjöldi eftir kyni og aldri 1841-2009. hagstofa.is/ apríl 2009.

14. Milos G, Spindler A, Schnyder U, Martz J, Hoek HW, Willi J. Incidence of severe anorexia nervosa in Switzerland: 40 years of development. Int J Eat Disord 2004; 36: 118-9.

15. Godart NT, Flament MF, Lecrubier Y, Jeammet P. Anxiety disorders in anorexia nervosa and bulimia nervosa: co-morbidity and chronology of appearance. Eur Psychiatry 2000; 15: 38-45.

16. Root TL, Pinheiro AP, Thornton L, et al. Substance Use Disorders in Women with Anorexia Nervosa. Int J Eat Disord 2010; 43: 14-21.

17. Kahn C, Pike KM. In search of predictors of dropout from inpatient treatment for anorexia nervosa. Int J Eat Disord 2001; 30: 237-44.

18. Strik Lievers L, Curt F, Wallier J, et al. Predictive factors of length of inpatient treatment in anorexia nervosa. Eur Child Adolesc Psychiatry 2009; 18: 75-84.

19. McKnight RF, Park RJ. Atypical antipsychotics and anorexia nervosa: a review. Eur Eat Disord Rev; 18: 10-21.

20. Carney T, Tait D, Richardson A, Touyz S. Why (and when) clinicians compel treatment of anorexia nervosa patients. Eur Eat Disord Rev 2008; 16: 199-206.

21. Santonastaso P. Compulsory treatment in anorexia nervosa. It J Psychopathology 2009: 205-9.

22. Skarderud F, Sommerfeldt B. [Self-harm and eating disorders]. Tidsskr Nor Laegeforen 2009; 129: 877-81.

23. Keel PK, Dorer DI, Eddy KT, Franko D, Charatan DL, Herzog DB. Predictors of mortality in eating disorders. Arch Gen Psychiatry 2003; 60: 179-83. 


\section{Anorexia nervosa in psychiatric units in lceland 1983-2008, incidence of admissions, psychiatric comorbidities and mortality}

Objective: Information is scarce concerning the incidence of anorexia nervosa (AN) in psychiatric facilities in Iceland. The aim of this study was to describe the incidence of admissions, comorbidity and mortality of patients who were admitted to psychiatric units in Iceland, diagnosed with AN in 1983-2008.

Material and methods: The study is retrospective. 140 medical records with an AN or atypical eating disorder diagnosis according to the ICD-9 and ICD-10 were reviewed. Final sample was 84 patients with confirmed AN diagnosis.

Results: Five men and 79 women were admitted to a psychiatric inpatient ward for the first time diagnosed with AN. Average age was 18.7 years. Incidence of admissions for both sexes in the first part of the study period (19831995 ) was $1.43 / 100.000$ persons/year, $11-46$ years old, but in the second part (1996-2008) 2.91. The increase was statistically significant $(\mathrm{RR}=2.0395 \% \mathrm{Cl} 1.28-3.22)$ and can mainly be explained by an increased incidence of admissions to the children- and adolescent psychiatric wards (CAW). Mortality of women was $2 / 79(2.5 \%)$ and standard mortality rate 6.25 . The average length of stay was 97 days, 67.3 days in adult units and 129.7 days in CAW $(p<0.05)$. In the study period 51 patients $(60.7 \%)$ were only admitted once. One patient had compulsory admission on his first admission but ten (11.9\%) had at some point compulsory admission. The body mass index increased in average from admission to discharge from 15.3 to $17.5 \mathrm{~kg} / \mathrm{m}^{2}$. A correlation was found between self harm and suicide attempts and compulsory admissions. Conclusion: The study revealed an increased incidence between periods. This might reflect a real increase of AN in the society. Mortality rate was lower than expected.

Sigurdardottir A, Palsson SP, Thorsteinsdottir G.

Anorexia nervosa in psychiatric units in Iceland 1983-2008, incidence of admissions, psychiatric comorbidities and mortality. Icel Med J 2010; 96: 747-53

Key words: anorexia nervosa, psychiatric comorbidity, incidence, psychiatric admission, mortality.

Correspondence: Guðlaug Porsteinsdóttir, gudlthor@landspitali.is

Barst: 10. júní 2010, - sampykkt til birtingar: 12. október 2010 Hagsmunatengsl: Engin 